\title{
TTR
}

Traduction, terminologie, re?daction

\section{Dror Abend-David. 'Scorned My Nation'. A Comparison of Translations of The Merchant Of Venice into German, Hebrew, and Yiddish. New York, Peter Lang, 2003, Comparative Cultures and Literatures, vol. 16, 247 p.}

\section{Sherry Simon}

Volume 18, numéro 1, 1er semestre 2005

Traductions et représentations : Parcours dans l'espace hispanique II Translations and Representations: Exploring the Hispanic World II

URI : https://id.erudit.org/iderudit/014375ar

DOI : https://doi.org/10.7202/014375ar

Aller au sommaire du numéro

Éditeur(s)

Association canadienne de traductologie

ISSN

0835-8443 (imprimé)

1708-2188 (numérique)

Découvrir la revue

Citer ce compte rendu

Simon, S. (2005). Compte rendu de [Dror Abend-David. 'Scorned My Nation'. A Comparison of Translations of The Merchant Of Venice into German, Hebrew, and Yiddish. New York, Peter Lang, 2003, Comparative Cultures and Literatures, vol. 16, 247 p.] TTR, 18(1), 251-252. https://doi.org/10.7202/014375ar d'utilisation que vous pouvez consulter en ligne. 


\section{COMPTES RENDUS}

Dror Abend-David. 'Scorned My Nation'. A Comparison of Translations of The Merchant Of Venice into German, Hebrew, and Yiddish. New York, Peter Lang, 2003, Comparative Cultures and Literatures, vol. 16, 247 p.

That The Merchant of Venice continues to fascinate and provoke both Jew and non-Jew is demonstrated most recently by Al Pacino's compelling performance in Michael Radford's 2004 movie of the Shakespearean play-just one of the latest contributions to a history that Pierre Lasry documents in his important 1999 National Filmboard documentary "Shylock." The study by Dror Abend-David sketches out this history from one particular perspective-that of the translations of the play into Yiddish and Hebrew. What image has Shylock represented for Jews? The question is a powerful one, when placed in the context of Harold Bloom's assessment that Shakespeare's Merchant of Venice is an undeniably anti-Semitic play, and that "to recover its comic splendour you have to be either a scholar or an anti-Semite, or best of all an anti-Semitic scholar” (Qtd, p. 13). But as Abend-David's study shows, this assessment is not universally shared in the Jewish tradition. In fact, translations into Yiddish and Hebrew have created positive Shylocks, reflecting the image of a philo-Semitic Shakespeare.

To investigate Jewish translations of The Merchant of Venice, Abend-David turns first to the German tradition-noting that the "uses" of Shylock by Jews themselves must be understood in relation to the rich German tradition of translations-not only in terms of the characterization given to Shylock but in relation to the national project which it embodied. The author follows the many translations and performances that established by the end of the $19^{\text {th }}$ century a distinct German tradition of reading, translating and performing the play. Yiddish and Hebrew critics and translators rework this tradition, divided between the tortured and maligned character of Shylock and the benign and praiseworthy Nathan of Lessing's play. The three appendices to this study give an idea of the material that the author took on. Each of the appendices is a chronological list of "Related Events, Performances and Translations" of The Merchant of Venice into respectively German, Yiddish and Hebrew. The first begins in 1585 with a group of English players performing at the Leipzig Rathaus and concludes 10 dense pages later with a 1999 performance in Hamburg. The second begins in 1817 and concludes in 1983 with a Yiddish 
performance of Shylock in London, England. Translations into Hebrew begin as early as 1816 (fragments) and continue through the 1990s.

In carefully developed explanations, the author shows how the play was pitched to Yiddish-speaking audiences through perspectives that argued, for instance, that 'educated Jews' need not be offended by the play since it criticizes the same qualities that Jewish intellectuals may wish to rectify (the religious conservatism and the ethnic seclusion of the Jewish people) or through social interpretations which see in Shylock a representative of a class of Jewish merchants whose wealth comes at the expense of the impoverished Jewish masses. Sometimes the negative qualities of Shylock become the marks of a "moral and intellectual superiority," and "black magic" is viewed positively as a "Cabalistic" victory in the spiritual realm that quickens the coming of the Messiah. The closeness of the relationship between the Yiddish and German traditions is revealed in the language itself. Daytshmerish is the term used to characterize Yiddish which is heavily Germanized. Translations into Yiddish had to negotiate the ideological and spiritual implications of language by either subscribing to or turning their back on the German language.

Abend-David discusses the translations, adaptations and rewritings within the larger context of the "national" projects that the translations serve. German translations were part of an important enterprise of nation-building, and the place of the Jew within this culture is crucial. The Hebrew translations, obviously enough, were part of another national project, this time clearly enlisted towards political empowerment. The author's extension of these questions to adaptations of the play revealing contemporary political tensions in the Middle East is evidence, yet again, of the continued power of the play to question political and religious values. The Merchant of Venice is part of modern Jewish history, and a text to which one must return, "however reluctantly" in order to explore the development of modern Jewish identity. 